HorTSCIENCE 26(3):304-307. 1991.

\title{
Growth Regulator and Axillary Bud Position Effects on in Vitro Establishment of Vitis rotundifolia
}

\author{
Sudarsono' ${ }^{1}$ and Ronald G. Goldy \\ Department of Horticultural Science, North Carolina State University, \\ Raleigh, NC 27695-7609
}

Additional index words. muscadine grape, micropropagation, benzylaminopurine,

kinetin, thidiazuron

\begin{abstract}
Four muscadine grape (Vitis rotundifolia Michx.) cultivars (Carlos, Noble, Regale, and Tarheel) were evaluated for their ability to be cultured in vitro. Axil1ary buds were placed on Murashige and Skoog medium as modified by Chee. Different levels of benzylaminopurine [(BA) 0.5 to $10.0 \mu \mathrm{M}$ ], kinetin [(KIN) 0.5 to $5.0 \mu \mathrm{M}$ ], and thidiazuron [(TDZ) 0.5 to $11.3 \mu \mathrm{M}$ ], and different explant positions were evaluated for their effect on in vitro explant establishment and shoot production. Thidiazuron $(2.3$ to $4.5 \mu \mathrm{M})$ alone or in combination with BA $(1.0$ to $5.0 \mu \mathrm{M})$ or KIN $(1.0$ or $5.0 \mu \mathrm{M})$ was effective for establishing axillary buds. Similar levels were also effective for promoting shoot proliferation. Explants originating from the $\mathbf{1 0}$ basal nodes of a shoot with at least 25 nodes gave better shoot proliferation than explants originating from the 10 distal nodes. Chemical names used: 6-benzylaminopurine, 6-furfurylaminopu. rine (kinetin): $N$-phenyl- $N$ '- 1,2,3 -thiadiazol-5-y lurea (thidiazuron).
\end{abstract}

Several cultivars of muscadine grape are important in wine production in the southeastern United States. However, there are problems in disseminating cultivars since clonal propagation of this species has proven to be difficult. Unlike Euvitis spp., dormant cuttings of muscadine do not root readily, even after exogenous auxin treatment (Goode et al., 1982). Micropropagation has been

Received for publication 27 July 1989. Paper no. 12309 of the Journal Series of the N.C. Agricultural Research Service, Raleigh, NC 27695-7643. Use of proprietary products or vendors does not constitute a guarantee or warranty of the products and does not imply its approval to the exclusion of other products or vendors that also may be suitable. We appreciate the technical assistance of Dana Moxley and advice on statistical data analysis of William H. Swallow. The cost of publishing this paper was defrayed in part by the payment of page charges. Under postal regulations, this paper therefore must be hereby marked advertisement solely to indicate this fact.

'Present address: Dept. of Crop Science, North Carolina State Univ., Raleigh, NC, 27695-7620. suggested as an alternative propagation method (Gray and Fisher, 1985; Lee and Wetzstein, 1990). A reliable micropropagation system is also a prerequisite for conducting in vitro studies for muscadine grapes.

Chee (1982) outlined six phases for micropropagation of grape (Euvitis spp.): 1) explant selection, 2) establishment in culture, 3) shoot production, 4) shoot multiplication from subculture shoots, 5) rooting of subculture shoots, and 6) transfer of regenerated plantlets to soil. Establishment in culture is critical since it is the initial step of culturing selected explants on defined media. The purposes of this phase are to establish explants under aseptic conditions, promote meristematic activity, and produce shoots for subsequent subculture (Chee, 1982). Explant origin also has a significant effect on survival and subsequent growth in culture (Fanizza et al., 1984; Yu and Meredith, 1986). We have also observed differences in response to growth regulator treatments as a function of explant origin in muscadine grape (unpublished data). 

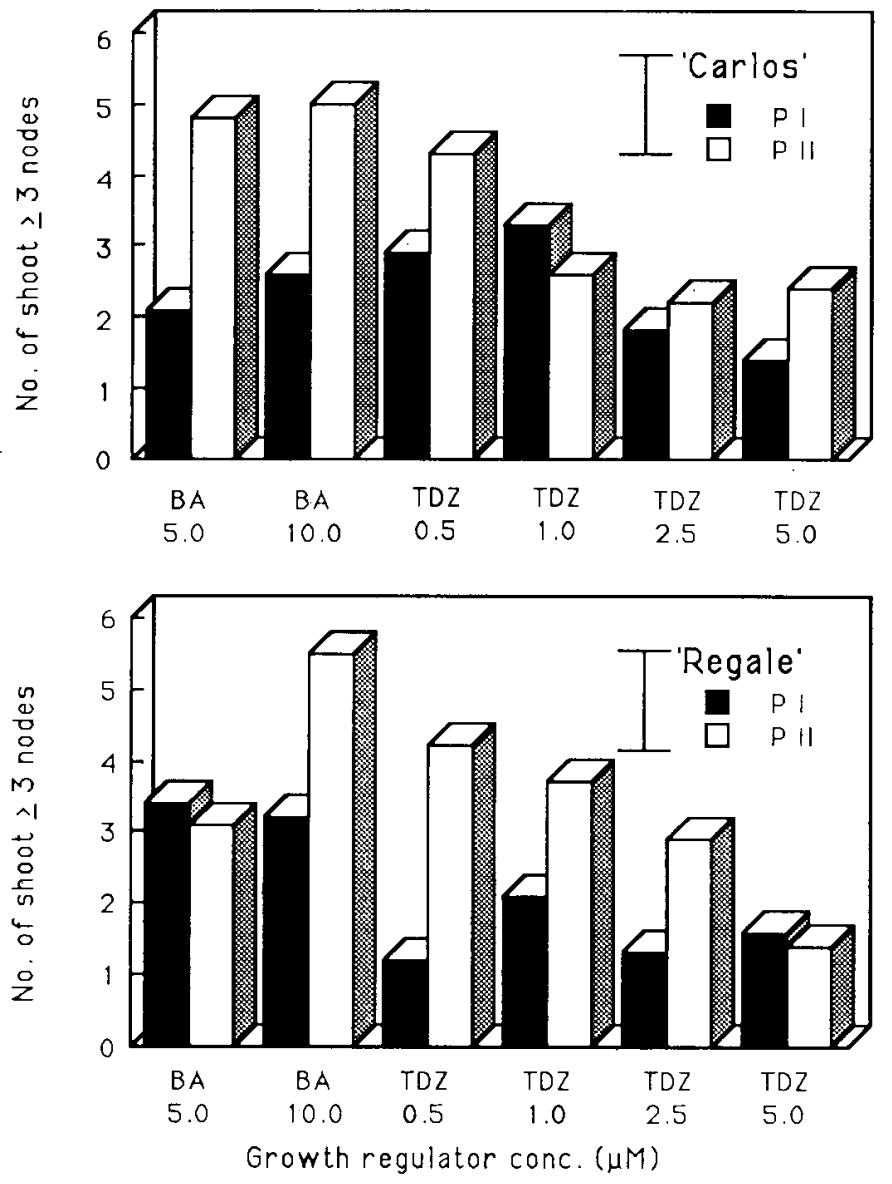

Fig. 1. Effect of explant position and BA or TDZ on average number of shoots having at least three nodes produced per explant after 60 days in culture. P-I: 10 distal nodes; P-II: 10 basal nodes from shoots having $\geq 25$ nodes. Vertical line indicates LSD at $F^{\prime}=0.05$.

Tissue culture of muscadine grape has proven to be more difficult thanEuvitis grapes (D.J. Gray, personal communication). In addition, our preliminary experiments showed that culturing muscadine axillary buds on medium developed for Euvitis spp. (Barlass and Skene, 1980; Chee and Pool, 1985, 1987; Chee et al., 1984), supplemented with 5 to $10 \mathrm{KM}$ BA, tended to induce excessive callus formation at the base of explants. This problem may affect subsequent shoot proliferation and shoot elongation. Since a high concentration of cytokinin is required for shoot proliferation, investigating alternative growth regulators that exhibit activity similar to BA, but without this negative effect, may be useful.

Cytokinin-like activity of thidiazuron (TDZ) has been reported in various tissue culture systems (Mok and Mok, 1985; Mok et al., 1987; Niewkerk et al., 1986). In some cases, activity of TDZ has been higher than that of adenine-derived cytokinins (Fellman et al., 1987; Mok and Mok, 1985). Comparison of TDZ to BA and kinetin (KIN) maybe useful in developing a suitable tissue culture system for $V$. rotundifolia. This report describes growth regulator and explant position effects on in vitro axillary bud establishment and subsequent shoot proliferation of four cultivars of $V$. rotundifolia.

Experiments were conducted to investigate: 1) effect of growth regulator on axillary bud establishment, 2) effect of growth regulator on shoot production, and 3 ) effect of explant origin on shoot production. To determine explant origin effects, shoots having at least 25 nodes were used. Two axillay bud positions were selected: the 10 distal nodes, designated position I (P-I), and the 10 basal nodes, position $\mathrm{H}$ (P-II). In other experiments any axillary bud origin was used, except the 10 distal ones.

Single-node cuttings of 'Carlos', 'Noble', 'Regale', and 'Tarheel' were obtained from actively growing greenhouse plants. After leaf removal, cuttings were Surface-sterilized in $1.3 \%$, followed by $0.7^{\prime} \%$, sodium hypochlorite for 25 and 10 rein, respectively, and rinsed three times in sterile distilled water. Explant size was reduced after sterilization by making cuts $1 \mathrm{~mm}$ above and below the axillary bud, yielding explants $\approx 3 \mathrm{~mm}$ long and 10 $\mathrm{mg}$ in weight.

Explants were cultured in $100 \times 15-\mathrm{mm}$ plastic petri dishes containing $25 \mathrm{ml}$ of medium. At initial culture, each treatment consisted of five plates, each containing five explants, and experiments were repeated twice. After 20 days, and every 20 days thereafter, entire cultures were transferred into 400-ml culture containers (Model GA7, Magenta Corp., Chicago) containing $50 \mathrm{ml}$ of fresh medium.

All experiments used a modified Murashige and Skoog (MS) medium (Chee et al.,
1984), supplemented with various levels of BA $(0.5$ to $10.0 \mu \mathrm{M}), \mathrm{KIN}(0.5$ to $5.0 \mu \mathrm{M})$, and TDZ (0.5 to $11.3 \mu \mathrm{M})$ (NOR-AM Chemical, Wilmington, Del.), depending on the experiment. In addition, 3\% (w/v) sucrose and $0.8 \%$ (w/v) Difco Bacto agar were added. Medium $\mathrm{pH}$ was adjusted to 5.7 before being autoclave at $121 \mathrm{C}$ for $15 \mathrm{~min}$ and cultures were incubated under a $28 / 25 \mathrm{C}$ day/night temperature regime and $16-\mathrm{hr}$ photoperiod from cool-white fluorescent lamps (photosynthetic photon flux 400 to $700 \mathrm{~nm}$ of 33.8 to $43.1 \mu \mathrm{mol} \cdot \mathrm{s}^{-1} \cdot \mathrm{m}^{-2}$ ).

Establishment was characterized after 40 days in culture by recording average fresh weight, percent bud survival, and percent of buds producing three-node shoots. Shoot production was measured by recording the average number of three-node shoots 60 days after initial culture. Data were analyzed using the General Linear Model (GLM) procedure of the Statistical Analysis System (SAS Institute, 1985) and means were separated using least square mean and pdiff options within GLM.

The medium reported for Euvitis (Chee, 1982; Chee et al., 1984) proved satisfactory for in vitro establishment of muscadine axillary buds. However, statistical analysis indicated significant cultivar and growth regulator interactions.

KIN was less active than BA or TDZ in promoting muscadine axillary bud growth and development (Table 1). The BA-KIN results agree with those reported for Euvitis bud culture (Goussard, 1981; Harris and Stevenson, 1982; Reisch, 1986). Explant survival in all treatments was generally similar; however, low average culture fresh weight and a lack of shoots having at least three nodes were observed on media containing KIN.

BA has been reported to be effective in enhancing axillary bud proliferation in several Euvitis species, with optimum levels between 5.0 to $10 \mu \mathrm{M}$ (Goussard, 1981; Gray and Fisher, 1985; Harris and Stevenson, 1982; Reisch, 1986). Out results showed that BA alone, up to $5 \mu \mathrm{M}$, even though more effective than KIN, generally was less effective for establishing muscadine axillary buds than TDZ alone (Table 1).

Effective in vitro axillary bud establishment was achieved on media containing TDZ $(0.5$ to $4.5 \mu \mathrm{M})$. A high percentage of survival and average fresh weight and high percentage of shoots having at least three nodes were observed on these media (Table 1). A higher TDZ level (1 $1.3 \mu \mathrm{M})$, however, caused shoot thickening and inhibited further shoot growth (data not shown).

Differences in the effects of BA and KIN, BA and TDZ, and KIN and TDZ combinations on explant establishment were observed (Table 2). The percentage of bud survival and percentage of buds producing shoots were generally similar among tested growth regulator combinations and concentrations. However, buds grown on media containing TDZ with BA or KIN frequently showed higher fresh weight than [hose on media with only BA and KIN. Differences in growth patterns were recorded among var- 
Table 1. Effect of BA, KIN, and TDZ on survival, shoot elongation, and fresh weight of 'Carlos', 'Noble', and 'Tarheel' grape axillary buds after 40 days in culture. . $^{\text {. }}$

\begin{tabular}{|c|c|c|c|c|c|c|c|c|c|}
\hline \multirow{2}{*}{$\begin{array}{l}\text { Plant } \\
\text { growth } \\
\text { regulator } \\
(\mu \mathrm{M})\end{array}$} & \multicolumn{3}{|c|}{ Carlos } & \multicolumn{3}{|c|}{ Noble } & \multicolumn{3}{|c|}{ Tarheel } \\
\hline & $\begin{array}{c}\text { Survival } \\
(\%)\end{array}$ & $\begin{array}{c}\text { Shoot } \geq 3 \\
\text { nodes } \\
(\%)\end{array}$ & $\begin{array}{c}\text { Fresh } \\
\text { wt } \\
(\mathrm{mg}) \\
\end{array}$ & $\begin{array}{c}\text { Survival } \\
(\%)\end{array}$ & $\begin{array}{c}\text { Shoot } \geq 3 \\
\text { nodes } \\
(\%)\end{array}$ & $\begin{array}{c}\text { Fresh } \\
\text { wt } \\
\text { (mg) }\end{array}$ & $\begin{array}{c}\text { Survival } \\
(\%)\end{array}$ & $\begin{array}{c}\text { Shoot } \geq 3 \\
\text { nodes } \\
(\%)\end{array}$ & $\begin{array}{c}\text { Fresh } \\
w t \\
(\mathrm{mg})\end{array}$ \\
\hline BA 0.5 & $53 \mathrm{~b}$ & $11 \mathrm{~cd}$ & $123 \mathrm{cde}$ & $47 \mathrm{bc}$ & $11 \mathrm{~cd}$ & $80 \mathrm{~d}$ & $47 \mathrm{~b}$ & $11 \mathrm{~cd}$ & $80 c$ \\
\hline 1.0 & ... & -.. & -.. & $18 \mathrm{c}$ & ... & $136 \mathrm{~d}$ & $67 \mathrm{ab}$ & -.- & $200 b c$ \\
\hline 2.5 & $87 a b$ & $43 b$ & $880 \mathrm{a}$ & $15 \mathrm{c}$ & $43 \mathrm{~b}$ & $794 \mathrm{c}$ & $53 \mathrm{~b}$ & $43 \mathrm{~b}$ & $417 \mathrm{ab}$ \\
\hline 5.0 & 95 a & $38 \mathrm{bc}$ & $504 \mathrm{~b}$ & $20 \mathrm{c}$ & $38 \mathrm{bc}$ & $234 d$ & $73 a b$ & $38 b c$ & $113 b c$ \\
\hline KIN 0.5 & 93 a & 0 & $17 \mathrm{e}$ & $26 \mathrm{c}$ & 0 & $20 \mathrm{~d}$ & $67 a b$ & 0 & $30 \mathrm{c}$ \\
\hline 1.0 & $53 \mathrm{~b}$ & 0 & $23 \mathrm{de}$ & $40 \mathrm{bc}$ & 0 & $33 \mathrm{~d}$ & $53 \mathrm{~b}$ & 0 & $20 \mathrm{c}$ \\
\hline 2.5 & $96 \mathrm{a}$ & 0 & $30 \mathrm{dc}$ & $33 \mathrm{bc}$ & 0 & $37 \mathrm{~d}$ & $67 a b$ & 0 & $23 c$ \\
\hline 5.0 & $80 \mathrm{ab}$ & 0 & $17 \mathrm{e}$ & $47 b c$ & 0 & $217 \mathrm{~d}$ & $60 \mathrm{~b}$ & 0 & $30 \mathrm{c}$ \\
\hline TDZ 0.5 & $93 \mathrm{a}$ & $69 \mathrm{a}$ & $867 \mathrm{a}$ & $87 \mathrm{a}$ & $69 \mathrm{a}$ & $1180 \mathrm{~b}$ & $100 \mathrm{a}$ & $69 \mathrm{a}$ & $280 a b c$ \\
\hline 2.3 & $87 \mathrm{ab}$ & $56 \mathrm{ab}$ & $360 \mathrm{bc}$ & $93 a$ & $56 a b$ & 1557 a & $67 a b$ & $56 \mathrm{ab}$ & $337 a b c$ \\
\hline 4.5 & $96 \mathrm{a}$ & $47 \mathrm{~b}$ & $345 \mathrm{bcd}$ & $67 \mathrm{ab}$ & $48 \mathrm{~b}$ & $887 \mathrm{bc}$ & $80 a b$ & $48 \mathrm{~b}$ & $560 \mathrm{a}$ \\
\hline 11.3 & ... & $\cdots$ & -.- & $47 \mathrm{bc}$ & -.. & $567 \mathrm{c}$ & $60 \mathrm{~b}$ & -- & $270 a b c$ \\
\hline
\end{tabular}

${ }^{2}$ Mean separation within columns by LSD, $P=0.05$. Percentages are means of percentages for individual petri plates.

'Dashes indicate missing valuc.

Table 2. Effect of TDZ and BA or KIN combinations on survival, shoot elongation, and fresh weight of 'Carlos', 'Noble', and 'Tarheel' grape axillary buds after 40 days in culture. ${ }^{z, y}$

\begin{tabular}{|c|c|c|c|c|c|c|c|c|c|}
\hline \multirow[b]{2}{*}{$\begin{array}{l}\text { Plant } \\
\text { growth } \\
\text { regulator } \\
(\mu \mathrm{M}) \\
\end{array}$} & \multicolumn{3}{|c|}{ Carlos } & \multicolumn{3}{|c|}{ Noble } & \multicolumn{3}{|c|}{ Tarheel } \\
\hline & $\begin{array}{c}\text { Survival } \\
(\%)\end{array}$ & $\begin{array}{c}\text { Shoot } \geq 3 \\
\text { nodes } \\
(\%)\end{array}$ & $\begin{array}{c}\text { Fresh } \\
\text { wt } \\
(\mathrm{mg})\end{array}$ & $\begin{array}{c}\text { Survival } \\
(\%)\end{array}$ & $\begin{array}{c}\text { Shoot } \geq 3 \\
\text { nodes } \\
(\%)\end{array}$ & $\begin{array}{c}\text { Fresh } \\
\text { wt } \\
(\mathrm{mg}) \\
\end{array}$ & $\begin{array}{c}\text { Survival } \\
(\%)\end{array}$ & $\begin{array}{c}\text { Shoot } \geq 3 \\
\text { nodes } \\
(\%) \\
\end{array}$ & $\begin{array}{c}\text { Fresh } \\
\text { wt } \\
(\mathrm{mg}) \\
\end{array}$ \\
\hline \multicolumn{10}{|l|}{$\mathrm{BA}+\mathrm{KIN}$} \\
\hline $0.5+0.5$ & $81 a b$ & $44 a b$ & $50 \mathrm{~d}$ & $73 a b c$ & 0 & $27 \mathrm{~d}$ & $\cdots$ & --- & $\cdots$ \\
\hline $0.5+1.0$ & $80 a b$ & $27 b c$ & $134 \mathrm{~cd}$ & $53 \mathrm{c}$ & $67 \mathrm{ab}$ & $477 \mathrm{bc}$ & $33 \mathrm{bcd}$ & $33 \mathrm{bc}$ & $290 \mathrm{abc}$ \\
\hline $1.0+0.5$ & $67 \mathrm{~b}$ & $60 a b$ & $263 \mathrm{~cd}$ & $69 \mathrm{bc}$ & $60 \mathrm{ab}$ & $854 \mathrm{~b}$ & $23 \mathrm{dc}$ & $24 \mathrm{bc}$ & $60 \mathrm{c}$ \\
\hline $1.0+1.0$ & $79 \mathrm{ab}$ & $20 b c$ & $83 \mathrm{~d}$ & $67 \mathrm{bc}$ & $7 c$ & $103 \mathrm{ed}$ & $27 \mathrm{cde}$ & $27 \mathrm{bc}$ & $143 \mathrm{bc}$ \\
\hline \multicolumn{10}{|l|}{$\mathrm{BA}+\mathrm{TDZ}$} \\
\hline $0.5+2.3$ & $100 \mathrm{a}$ & $64 \mathrm{a}$ & $760 \mathrm{ab}$ & $86 a b$ & $80 a$ & $1600 \mathrm{a}$ & 40 bcd & $40 \mathrm{abc}$ & $539 a b$ \\
\hline $0.5 \div 4.5$ & $82 a b$ & $4 \mathrm{c}$ & 350 bed & $60 \mathrm{c}$ & $40 \mathrm{bc}$ & $680 \mathrm{~b}$ & $7 \mathrm{e}$ & $7 c$ & $317 a b c$ \\
\hline $1.0+2.3$ & $100 a$ & $73 a$ & $890 \mathrm{a}$ & $80 \mathrm{abc}$ & $73 a b$ & $1500 \mathrm{a}$ & $47 \mathrm{bc}$ & $47 \mathrm{ab}$ & $310 \mathrm{abc}$ \\
\hline $1.0+4.5$ & -. & -.. & --- & 93 a & $47 a b$ & $830 \mathrm{~b}$ & $27 \mathrm{cde}$ & $27 \mathrm{bc}$ & $457 \mathrm{abc}$ \\
\hline \multicolumn{10}{|l|}{$\mathrm{KIN}+\mathrm{TDZ}$} \\
\hline $0.5+2.3$ & $67 \mathrm{~b}$ & $47 \mathrm{ab}$ & $370 \mathrm{bcd}$ & $67 \mathrm{bc}$ & $47 a b$ & $800 \mathrm{~b}$ & $50 a b$ & $50 \mathrm{ab}$ & $419 a b c$ \\
\hline $0.5+4.5$ & $87 \mathrm{ab}$ & $40 a b c$ & $300 \mathrm{~cd}$ & $60 \mathrm{c}$ & $60 a b$ & $1473 a$ & $70 \mathrm{a}$ & $70 \mathrm{a}$ & 718 a \\
\hline $1.0+2.3$ & $80 a b$ & $47 \mathrm{ab}$ & $560 a b c$ & $73 a b c$ & $73 \mathrm{ab}$ & $1520 \mathrm{a}$ & $30 \mathrm{bcd}$ & $30 \mathrm{bc}$ & $254 \mathrm{bc}$ \\
\hline $1.0+4.5$ & $100 \mathrm{a}$ & $40 a b c$ & $293 \mathrm{~cd}$ & $73 \mathrm{abc}$ & $53 \mathrm{ab}$ & $887 \mathrm{~b}$ & $24 \mathrm{de}$ & $24 \mathrm{bc}$ & $340 \mathrm{abc}$ \\
\hline
\end{tabular}

${ }^{2}$ Mean separation within columns by $L S D, P=0.05$. Percentages are means of percentages for individual petri plates.

yashes indicate missing value.

Table 3. Effect of TDZ and BA or KIN combinations on the number of shoots having at least three nodes produced by each 'Carlos', 'Noble', 'Regale', and 'Tarhecl' grape axillary buds after 60 days in culture.

\begin{tabular}{lcccc}
\hline \hline \multirow{2}{*}{$\begin{array}{l}\text { Plant growth } \\
\text { regulator }(\mu \mathrm{M})\end{array}$} & \multicolumn{4}{c}{ Shoots with more than three nodes (no.) } \\
\cline { 2 - 5 } & Carlos & Noble & Regale & Tarhecl \\
\hline TDZ 2.3 & $10.0 \mathrm{a}$ & $2.1 \mathrm{c}$ & $3.9 \mathrm{ab}$ & $4.5 \mathrm{~b}$ \\
+ BA 1.0 & $10.1 \mathrm{a}$ & $2.3 \mathrm{cdc}$ & $3.5 \mathrm{bcd}$ & $6.2 \mathrm{a}$ \\
+ BA 5.0 & $10.5 \mathrm{a}$ & $2.5 \mathrm{~b}-\mathrm{e}$ & $3.1 \mathrm{~d}$ & $6.8 \mathrm{a}$ \\
+ KIN 1.0 & $9.8 \mathrm{ab}$ & $2.4 \mathrm{cdc}$ & $4.4 \mathrm{a}$ & $5.3 \mathrm{ab}$ \\
+ KIN 5.0 & $8.5 \mathrm{~b}$ & $2.2 \mathrm{dc}$ & $4.0 \mathrm{ab}$ & $4.0 \mathrm{bc}$ \\
TDZ 4.5 & $6.8 \mathrm{c}$ & $2.9 \mathrm{bc}$ & $4.1 \mathrm{a}$ & $6.5 \mathrm{a}$ \\
+ BA 1.0 & $7.8 \mathrm{bc}$ & $2.8 \mathrm{bcd}$ & $3.9 \mathrm{abc}$ & $6.0 \mathrm{a}$ \\
+ BA 5.0 & $7.7 \mathrm{bc}$ & $3.1 \mathrm{ab}$ & $3.1 \mathrm{~d}$ & $4.8 \mathrm{~b}$ \\
+ KIN 1.0 & $7.3 \mathrm{bc}$ & $3.7 \mathrm{a}$ & $3.2 \mathrm{~cd}$ & $5.2 \mathrm{ab}$ \\
+ KIN 5.0 & $9.7 \mathrm{ab}$ & $2.7 \mathrm{~b}-\mathrm{c}$ & $3.4 \mathrm{bcd}$ & $6.2 \mathrm{a}$ \\
\hline
\end{tabular}

${ }^{2}$ Mean separation within columns by LSD, $P=0.05$.

ious growth regulator treatments. Multiple shoots formed among buds grown on media containing TDZ and BA or KIN while single shoots elongated on media with BA and KIN.

Further investigation on the effect of growth regulator combinations on shoot production showed that TDZ alone or TDZ in combination with BA or KIN generally gave similar results (Table 3). The response, however, proved to be cultivar dependent. The best response was observed with 'Carlos', followed by 'Tarheel', 'Regale', and 'Noble'.

No callus formation at the base of explants was observed among buds grown on TDZcontaining media. In these experimental conditions, TDZ alone was adequate for inducing shoot proliferaition. However, addition of BA or KIN into TDZ-containing medium resulted in an increased number of nodes (data not shown). In addition, wide differences in cultivar response to growth regulator treatments were observed.

Time of exposure on media containing TDZ was critical for subsequent shoot proliferation. Although cultures initially grew well, tissue browning and senescence were observed on the growing explant during the culture periods if the cultures were not regularly transferred. Sipes and Einset (1983) found TDZ to induce senescence in cultured lemon [Citrus limon (L. ) Burro. f.] pistils. They postulated that this was due to TDZ stimulating ethylene production, which in turn caused senescence. Other factors that may contribute to this effect are rapid depletion of nutrients and cytokinin toxicity. In our experimental conditions, transferring cultures every 20 days (o fresh medium overcame browning and senescence.

Axillary bud origin has a significant effect on growth and development of Euvitis explants in culture (Fanizza et al., 1984; Yu and Meredith, 1986). Vitis rotundifolia showed differences in shoot production between axillary buds taken from different positions (Fig. 1).

Shoot production during establishment and subsequent shoot proliferation phases is re- 
lated to the number of pre-existing axillary bud primordia on the original explant (Chee, 1982). Variation in shoot number may also be due to differences in effectiveness of growth regulator treatments in promoting growth of pre-existing axillary bud primordia. The generally higher number of shoots produced from $\mathrm{P}-\mathrm{H}$ buds may be due to a greater number of pre-existing axillary bud primordia in the explant, whereas differences among treatments within explant positions may reflect differences in growth regulator effectiveness. Novak and Juvova (1980) reported an increase in shoot production from buds of Euvitis grapes with increasing distance from the apex. Under our experimental conditions, survival of explants from different explant origins was not a problem if sufficient growth regulator concentration was supplied.

Application of a single in-vitro technique across several cultivars of $V$. rotundifolia should be successful using the following steps: 1) Select the most basal buds of rapidly growing, nonlignified shoots; 2) use Murashige and Skoog basal medium as modified by Chee (1984); and 3) supplement basal medium with TDZ (2.3 to $4.5 \mu \mathrm{M})$ alone or in combination with BA (1.0 to $5.0 \mu \mathrm{M})$ or KIN (1.0 to $5.0 \mathrm{KM})$. In addition, transferring cultures every 20 days onto fresh medium will reduce browning and senescence.

\section{Literature Cited}

Barlass, M. and K.G. M. Skene. 1980. Studies on the fragmented shoot apex of grapevine. II. Factors affecting growth and differentiation in vitro. J. Expt. Bet. 31:483+88.

Chee, R. 1982. In vitro micropropagation of Vitis. PhD Diss., Cornell Univ., Ithaca, N.Y.

Chec, R. and R.M. Pool. 1985. In vitro propagation of Vitis. The effect of organic substances on shoot multiplication. Vitis 24: 106-1 18.

Chee, R. and R.M. Pool. 1987. Improved inorganic media constituents for in vitro shoot multiplication of Vitis. Scientia Hort. 32:85-95.

Chee, R., R.M. Pool, and D. Bucher. 1984. A method for large scale in vitro propagation of Vitis. N.Y. Food and Life Sci. Bul. 109:1-9.

Fanizza, G., O.A. Tanzarclla, G. Carrozzo, and B. Greco. 1984. Influence of Vitis source on in vitro shoot apex culture. Ann. Applied Biol. 104:577-578.

Fellman, C. D., P.E. Read, and M.A. Hosier. 1987. Effect of thidiazuron and CPPU on meristem formation and shoot proliferation. HortScicnce 22:1197-1200.

Goode, D . K. , Jr., G.W. Krewer, R.P. Lane, and J.W. Daniel. 1982. Rooting studies of dormant muscadine grape cuttings. HortScience 17:644645.

Goussard, P.G. 1981. Effects of cytokinins on elongation, proliferation and total mass of shoots derived from shoot apices of grapevine cultured in vitro. Vitis 20:228-234.

Gray, D.J. and L.C. Fisher. 1985. In vitro shoot propagation of grape species, hybrids and cultivars. Proc. Fla. State Hort. Soc. 98:172-174.

Harris, R.E. and J.H. Stevenson. 1982. In vitro propagation of Vitis. Vitis 21:22-32.

Lee, N. and H.Y. Wetzstcin. 1990. In vitro propagation of muscadine grape by axillary shoot proliferation. J. Amer. Soc. Hort. Sci. 115:324 329.

Mok, M.C. and D.W.S. Mok. 1985. The metab- olism of $\left[{ }^{14} \mathrm{C}\right]$ thidiazuron in callus tissues of Phaseolus lunatus. Physiol. Plantarum 65:427432.

Mok, M. C., D.W.S. Mok, J.E. Turner, and C.V. Muier. 1987. Biological and biochemical effects of cytokinin-active phenylurca derivatives in tissue culture systems. HortScience 22: 1194 1197.

Niewkerk, J. P., R.H. Zimmerman, and I. Fordham. 1986. Thidiazuron stimulation of apple shoot proliferation in vitro. HortScicncc 21:516518.

Novak, J. and Z. Juvova. 1980. Hormonal regulation of the development of isolated grapevine shoot tips (Vitis sp. ) under in vitro conditions. Sbor. Uvtiz-Ochr. Rostl. 16:241-252.

Reisch, B.I. 1986. Influence of genotype and cytokinins on in vitro shoot proliferation of grapes. J. Amer. Soc. Hort. Sci. 111:138-141.

SAS Institute. 1985. SAS user's guide: Statistics. SAS Inst., Inc., Cary, N.C.

Sipes, D.L. and J.W. Einset. 1983. Cytokinin stimulation of abscission in lemon pistil explants. J. Plant Growth Reg. 2:73-80.

Yu, D,H. and C.P. Meredith. 1986. The influence of explant origin on tissue browning and shoot production in shoot tip cultures of grapevine. J. Amer. Soc. Hort. Sci. 111:972-975. 